\title{
Community Land Trusts: A Case for an Expansive View of Reparations for Black Americans
}

\author{
Sydni Scott, Columbia University
}

\begin{abstract}
The concept of reparations for black Americans - as a means of rectifying the economic inequality that has resulted from historical legacies of slavery and subsequent racially discriminatory policies - has been defined in American political discourse by its narrow scope of focus and dismal levels of public support. This paper explores an expansive idea of reparations beyond federal or state cash-payouts in the form of Community Land Trusts, which are nonprofit organizations designed to create permanently affordable housing. We begin with an argument for the inefficacy of race-neutral policy in reducing the racial wealth gap and the necessity of race-conscious policy. Next is an evaluation of Community Land Trusts as political mechanisms for reparations, their benefits, drawbacks, and future potential. Finally, this paper presents a challenge to the assumption that reparations policies are so unpopular as to make them politically infeasible, including putting competitive threat theory and exposure theory in conversation with contemporary public opinion polling data.
\end{abstract}

\section{Introduction}

In 2016, the median net worth of white households in the U.S. was $\$ 171,000$. In contrast, the median income for black households was nearly ten times less than that: $\$ 17,150$. According to the Census Bureau's Survey of Consumer Finance, in 2010, white Americans owned $88.4 \%$ of the nation's wealth. Black Americans owned just 2.7\% (McIntosh et al. 2020). There are few political phenomena in the United States as pervasive as the racial wealth gap. This undeviating feature of American politics and culture permeates every major institution: education, housing, the justice system, healthcare, employment. While progressive policy has meandered along a trajectory of increasing civil rights and equality for black Americans, this progression is ultimately stunted by inaccessibility to institutions that allow for the growth of generational black wealth. Although there are many institutions that can allow for acquisition, the dynamic of race-based economic inequality is foundationally bellied by the inability for black Americans to access the stability of safe and secure housing necessary for accumulation of wealth. This essay is broken down into four parts. I will begin by briefly describing the historical context that contributed to modern economic demographics. Then, I will address the dissonance between race-neutral and raceconscious policy and argue with examples as to why the former is ineffective. Next, I will introduce the efficacy of race-conscious policy through the lens of Community Land Trusts and analyze their potential impact on wealth building. Last, I will discuss some limitations of Community Land Trusts, but why now in particular is the optimal time to advance it as a race-conscious policy in the United States.

Contemporary racial wealth inequality was driven by a series of policies that have adapted throughout the $19^{\text {th }}$ and $20^{\text {th }}$ centuries to contend with developing civil 
rights legislation and bar black Americans from accessing means of building capital. In the immediate aftermath of the Emancipation Proclamation, Union General William T. Sherman's Special Field Order 15 , better known colloquially as " 40 acres and a mule" granted freed black Americans up to 40 acres of tillable land, and in some cases, an army mule to jump-start their introduction as wage-earners to the U.S. economy. Unfortunately, after the assassination of Abraham Lincoln, his successor, Andrew Johnson, reversed the order in 1865 and returned the land to former confederate southerners, leaving newly freed black people with few options other than becoming sharecroppers for former slave owners (McCammon 2015). This trajectory has continued throughout contemporary American history, and black Americans experienced disenfranchisement in almost every institution.

An analysis of policy that disenfranchised black Americans from 1865 to the present, though compelling, is beyond the scope of this paper; instead, I will focus on a series of policies implemented in the 1930s that significantly impacted modern institutions of housing and the demographic distribution of wealth that ensued. Broadly I'm referring to the New Deal, which served the purpose of generating access largely to housing support in the U.S. While a similar law, the G.I bill, didn't allow black veterans to access all the educational resources afforded to white veterans because the educational institutions in question employed the use of segregation policies, the Federal Housing Administration (FHA) similarly instituted the practice of redlining in combination with New Deal government subsidies and grant programs for mortgage financing (Katznelson 2005). The Homeowners Loan Corporation, FHA, and Veterans Administration used maps of metropolitan areas and color-coded them based on where it was considered safe to insure. All sections where black Americans lived - or were proximate to - were color coded as red and were considered too risky to issue mortgage loans (Rothstein 2018).

In his 2017 book The Color of Law, Richard Rothstein details both the history behind the laws and the ramifications on future racial wealth inequity. Essentially, these practices were justified on the grounds that if black Americans were able to buy property in or near white suburbs, the value of those properties would decline. In actuality, however, this logic was empirically inaccurate. Black people with the means were often willing to pay more for properties because their housing options were already so limited, which increased the property values of those homes (Rothstein 2018). However, The Underwriting Manual of the FHA decreed that "incompatible racial groups should not be permitted to live in the same communities," and African Americans couldn't get loans for those properties. In one particular example in Detroit, the FHA wouldn't proceed with lending until developers constructed a 6foot-high cement wall separating the development from a nearby black neighborhood. Even black potential property buyers with the credit to afford loans were barred from purchasing property in developing suburbs (Rothstein 2018).

These policies lasted from the 1930s until the late 1960s when the 1968 Fair Housing Act was passed, finally prohibiting the policy (U.S. Department of Housing and Urban Development). However, by then, while technically legally allowed to purchase property in predominantly white suburbs, the property values in those neighborhoods had increased so much that they were no longer affordable to black homeowners that had been segregated into poorer neighborhoods with worse job 
prospects and education. White Americans, on the other hand, had been able to build equity in those properties that could be used to fund everything from college tuitions to entrepreneurial pursuits. This financial freedom came largely in the form of $\$ 120$ billion in government housing subsidies between 1934 and 1962, an estimated 98\% of which were awarded to white Americans (Lipsitz 2008). In the Color of Law, Rothstein estimates that houses funded by New Deal era subsidies are currently valued between $\$ 300,000$ and \$400,000 (Rothstein 2018).

These effects are still relevant today because accumulated capital and income operate dramatically differently in the United States. In order to comprehensively evaluate the relationship between race-neutral policy and the racial wealth gap, it is first necessary to establish the way in which wealth inequality functions. To do so, I look to French economist Thomas Piketty. In his seminal work, Capital in the Twenty-First Century, Piketty first describes the distinction between distribution of wealth and income, or in other terms, return on capital vs. wagebased earnings. The reason he focuses on this distinction is because his work centers around "changes in the relative importance of inherited wealth and savings in the... dynamics of wealth inequality" (Piketty 2017). Piketty developed an economic model whereby if the rate of return on capital exceeds the rate of growth in a particular country, then wealth inequality is self-perpetuating because accumulation of wealth is more profitable than labor-based wages (Solow 2014). The trajectory of the United States included a ratio of 5:1 in 1910, falling slightly in the following decade before rising again to 5.5:1 around the time of World War II. Finally, it fell to below 4:1 in 1950, and has been steadily on the rise ever since.
As it stood by 2010 , the ratio was at $4.5: 1$. A concerning component of Piketty's findings includes the fact that these climbing ratios weren't emblematic of market instability, and in fact, occur while the market is functioning under conditions economists would describe as efficient (Solow 2014). Piketty's model warrants further exploration in the coming sections, but the connection between his model and the effects of housing discrimination is persuasive considering current discrepancies. While as of 2017 , black wages were around $60 \%$ of total white wages, total black wealth was instead just 5\% of white wealth (Rothstein 2018).

\section{Race-Neutral Policy}

Having discussed the trajectory of discriminatory policy that contributed to the racial wealth gap as it stands today, I will move forward with the central argument of this section. A racial disparity that grew out of explicitly racist policies can only be rectified through contemporary policy that acknowledges race. I draw this conclusion from recognition of interconnected institutions that cause race to impact policy outcomes even if race is absent from the written laws. This deduction is in direct contrast with what are known as race-neutral or universal policies. I argue that raceneutral policies, though worthwhile, are largely ineffective at reducing the racial wealth gap. First, this is because American institutions conform to the standards Piketty identified. Universal policies are still inherently organized to reward wealth rather than wage-based labor. This is exemplified not only in the structure of our tax policythe Center on Budget and Policy reported that the 2017 tax policy allows for significant tax breaks on income from wealth that income from labor does not experience- but also in policies that are 
ostensibly intended to alleviate wealth inequality (Huang 2019).

For example, Social Security, a federally funded insurance program that consists of retirement, disability, and survivor benefits, is undeniably beneficial to black Americans. However, this is in large part because they oftentimes have fewer alternative retirement assets, simply meaning much of total social security paid out by the government goes to black Americans (Hendley n.d 2020). Further, there are in fact components of Social Security policies that seek to rectify wealth inequality. One such program is the Progressive Benefit Formula. Broadly, workers with lower wages proportionately receive more benefits than workers with higher wages. This significantly serves black workers who average lower wages than white workers. However, even though the Social Security benefit formula is progressive in that it allows for low earners to qualify for higher proportions of their preretirement earnings, workers with lower earnings still receive lower dollar benefits due to the function of proportion. The actual dollar amount black Americans receive in benefits is lower than for white Americans because of their lower overall earnings (Hendley n.d 2020). This disproportionate dollar amount means that this policy does little to amend the racial wealth gap as we understand it from Piketty.

The second reason is because the nature of interconnected American institutions causes racial implications even from seemingly disconnected systems. For example, while many healthcare policies and medical standards employ the use of "race correction" in algorithms, much of healthcare legislation contains no overt racial language (Malina 2021). However, the implementation ignores race in such a way that allows black Americans to be excluded from the benefits consistently. This can include observable surface-level trends such as the fact that in 2018, the percentage of white Americans that were uninsured was around 5.4\% while the same uninsured rate for black Americans was almost double at 9.7\% (Taylor 2019). However, it also includes factors that differentiate poor black Americans from poor white Americans. For instance, Medicaid is subject to regional stipulations, and in 2018, many Southern states with large black populations imposed strict employment requirements for certain Medicaid recipients, and individuals who couldn't meet the requirements were allowed ninety days before their Medicaid status was terminated (NASHP 2018). Access to the job market is variable along racial lines that isn't accounted for by using income as a proxy. A 2003 study from the National Bureau of Economic Research found that, considering candidates with identical merit, a white man with a former felony conviction is more likely to get a call back for a job than a black man with a clean record, and the gap widens dramatically if the black applicant has a criminal record (NBER 2003). In response to the policy alteration, a disproportionate number of black Americans - 18,000 people-lost their health insurance in 2018 due to their inability to obtain jobs that met the employment qualifications (NASHIP 2018).

Many universal policies aren't ineffective because of overt racial language. Instead, they're ineffective because they ignore factors that are most critical to the propagation of the racial wealth gap and the policies necessary to overcome it. They shape colorblind policy in a society in which race is one of the most salient social factors. As a result, even with race-neutral policies in place, the racial wealth gap has only worsened. A 2017 report by the Institute for Policy Studies found that between 1983 and 2013, Median Hispanic household wealth declined 50\%, black median household 
wealth declined $75 \%$ and median white household wealth increased 14\% (Asante Muhammad et al. 2017).

The purpose of focusing on housing is borne out of the myriad inequalities that stem from housing inequality. For example, despite the prohibition of segregation in 1964, today over $50 \%$ of students attend either predominantly white or predominantly nonwhite schools. What's more, a 2019 study from EdBuild found that there exists a $\$ 23$ billion discrepancy in the funding of predominantly white schools versus predominantly black and predominantly non-white schools when controlled for the number of students (EdBuild 2019). While multiple funding strategies are at play, the allocation of public-school funding tied to local property taxes grounds this phenomenon. This dynamic is replicated in institutions beyond education as well. Using census tract-level data, a 2009 study found that race, specifically blackness, is a more accurate predictive measure of whether someone will live in proximity to environmental and climate hazards than income and poverty (Downey 2009). Mobility in housing acquisition is requisite in addressing racial inequity across many American institutions.

\section{Race-Conscious Action}

In November of 2019, by an 8-1 vote, the City Council of Evanston, Illinois officially began its reparations program to the black residents of the city. Any black resident that lived in Evanston between 1919 and 1969 and was the victim of any housing discrimination is entitled to government assistance to fund the purchase of permanent housing. The funding for this endeavor will come from sales tax on recently legalized marijuana, partially in acknowledgement of the disproportionate harms of the War on Drugs for black Americans. (Evanston City
Council 2019). With this design, benefits are directly targeted at an identifiable and distinguishable group of black Americans that were the victims of explicitly discriminatory policy, directly benefit the expansion of black homeownership, and, significantly, doesn't pose any additional annual tax burden on Evanston's other residents. While it was the first, Evanston has instigated a larger-scale movement for reparations that is ongoing at the time this paper was written. This momentum includes HR-40 - a bill introduced by the late Rep. John Conyers - passing through the House Judiciary Committee for the first time since its introduction 32 years ago (Fandos 2021).

The purpose of this paper necessitates exploration beyond making a case for reparations, but it's necessary to address the choice of reparations as the mechanism by which I argue the rectification of the racial wealth gap should be pursued. While pejorative in its association with cash payouts, a reparative justice framework simply demands the acknowledgement of past harms and historical context in development of solutions to contemporary inequality. In accordance with the United Nations Human Rights Office of the High Commission, reparations require: first, cessation of harm and guarantees of nonrepetition, second, restitution to the status before harm when possible, and third, compensation and rehabilitation when restitution is impossible (OHCHR). While policies meant to further racial equality in an exclusively modern context are valuable, they often fail to reduce the racial wealth gap because they fail to address the fundamental and historical sources of inequality. For this reason, I don't present reparations as a single policy item, but rather a methodological lens through which we must structure policy on racial equity. 
Evanston's reparations resolution exists as a challenge to the long-held belief that reparations is an infeasible policy solution. However, the practice of funding private grants that provide financial aid to lowincome buyers in either their down payments or their mortgages leaves much room for increased sustainability, a necessary qualification for rectifying generationally codified racial discrimination. In this scenario, after making payments to the mortgage and developing equity in the home, the original buyers can sell it for a price that has become inaccessible to other low-income individuals and families, therefore making the grant an intrinsically unsustainable solution.

Enter Community Land Trusts. Land trusts are non-profit organizations that seek to provide affordable permanent housing to low-income communities by acquiring multiple plots of land scattered across a specific geographic location and allowing for private development on top of the land. Critically, the land is never resold and instead is removed permanently from the market on behalf of the target community. Because ownership of the land itself is never transferred outside the bounds of the land trust, it can support the permanent ownership of housing. The trust issues a long-term ground lease of the land to the owners of the property that is typically up to 99 years. This lease - a small monthly payment - is heritable, renewable, and mortgageable (Davis 2014).

To illustrate the significance of this approach, I will provide an example of how this concept works in practice: A land trust, typically privately funded, acquires parcels of land in a given city through either purchase or donation. They can fund the development of residential buildings, and then put them up for sale specifically to lowincome prospective buyers. Those buyers are able to establish manageable mortgages for their property, as well as invest in them with the knowledge that the property value won't increase beyond their means. This is because land trusts maintain mostly constant prices that aren't influenced by the movement of the conventional housing market and are instead tethered to local incomes. Therefore, that grant funding is only beneficial once. Instead, with land trusts, the terms of purchase necessitate that owners either sell their property back to the land trust, or to other low-income property buyers. Therefore, a location of permanently affordable housing is established. Land trust housing also protects owners from downturns because residents are not overextended.

Moreover, a 2010 study by Emily Thaden and Greg Rosenburg of 96 land trusts across the country found that land trust homeowners were 10 times less likely to be in foreclosure proceedings and 6.6 times less likely to be seriously delinquent than conventional homeowners, a result that is particularly significant given the lower income limits usually restricting land trust home buyers (Thaden 2011). To end this overview of land trusts, the last critical factor to note is that in 1992 an amendment to the National Affordable Housing Act lent land trusts a formal definition that allowed them to access federal funding through grant acquisition. After 1992, land trusts were allowed to qualify as a "Community Housing Development Organization "(CHDO). Because of this distinction, many more were able to receive funding from the federal HOME program through HUD in order to supply their operations and their future projects (Palmer 2019).

This basic structure of a land trust is still distinct however, from a Community Land Trust. A Community Land Trust functions in the same way but is modeled with three 
values at its focal point: ownership, organization, and operation. In addition to residential housing, CLTs encourage the development of shared commercial spaces including businesses and community centers. Most commonly, at least one-third of a Community Land Trust's board is composed of community residents in addition to real estate experts, benefactors, and business professionals, allowing for the possibility of direct participation in decision-making and community control of local assets. In addition to the development of affordable housing, many land trusts are involved in a range of community-focused initiatives including homeownership education programs, commercial development projects, and community greening efforts (Davis 2014). What's more, Community Land Trusts are developed based on the needs of the specific communities they serve and can prioritize anything from agricultural development to corporate pursuits. Having outlined the basic structure of a CLT, I will now evaluate the beneficial impact they can have on the ability for black Americans to participate in different sectors of political and social life.

Community Land Trusts aren't entirely new. What is widely acknowledged as the first CLT was called New Communities Inc. and it was established in Georgia in 1969 by Robert Swann, Slater King, and Charles Sherrod (Palmer 2019). Since their inception, CLTs have developed around the country, and as it currently stands, there are over 260 CLTs in forty-six states, Puerto Rico and D.C. (Davis 2014). While not all specifically race-based, these developments have provided the opportunity to gather empirical data about their efficiency, as well as the impact that they can have on economic inequality. For example, Myungshik Choi published a study in the Journal of Urban Affairs in 2017 that explored CLTs effectiveness at preventing and slowing gentrification. The author used a population of all active CLTs in the U.S. at the time of the study that were listed in the National Community Land Trust Network and then compared four categories: gentrifying neighborhoods with no CLTs, gentrifying neighborhoods with CLTs, nongentrifying neighborhoods with no CLTs, and non-gentrifying neighborhoods with CLTs. The qualifications for gentrification tracked the rate of increase of the white population, college-educated people, median income, median value of single-family homes, and percentage of owner-occupied units all against the corresponding citywide medians. They concluded that not only do CLTs alleviate the impacts of gentrification where it occurs, they also decrease the odds of gentrification by $74 \%$. In addition, the findings suggested that CLTs yield community assets in neighborhoods by improving their stability. Essentially, because of this it was concluded that CLTs can serve to benefit both residents and local municipalities regardless of whether they're gentrifying. Lastly, it was deemed that CLTs make for ideal proposals for community representatives because Choi demonstrated that they increase racial diversity while maintaining neighborhood standards for middle-class ratios, educational levels, and the rate of homeownership (Choi 2017). These community scale impacts are also mirrored by smaller changes. Similar to Thaden and Rosenburg's finding from 2010, the Lincoln Institute found that the rate of foreclosure and mortgage delinquency is significantly lower in CLTs and what's more, provide stability for generational wealth (DeWolf 2018).

This stability is critical because in addition to secure housing as a benefit of its own accord, stability is also a fundamental necessity for growth of additional wealth generating ventures like black business and entrepreneurship. The Kauffman Institute's 
2016 report finds that access to entrepreneurial economic mobility is often hindered at the foundation. "95 percent of African American and 87 percent of Latino middle-class families do not have enough net assets to meet most of their essential living expenses for even three months if their source of income were to disappear. People of color do not have the assets to take the risk of entrepreneurship, to quit their jobs, and bet on a new idea" (Desai 2020) The solutions outlined in the report include creating access to new social networks, pursuing alternative credit score methods, and developing pipelines for minorities to access professional education programs. Community Land Trusts are poised to facilitate all of these growth solutions by fostering an environment of growth and support, cultivating access to new sources of credit, and offering educational tools to capitalize on the stability provided (Davis 2014). Lastly, they provide proximate and affordable commercial spaces for developing black businesses.

Despite overwhelming empirical evidence supporting the efficacy of CLTs and their impact on residents' financial mobility, they're not without their valid critiques. The first of these critiques is that without the ability to build equity as property value increases as is possible in the conventional housing market, black homeowners are still being undercut in their ability to acquire wealth (Foster 2019). While true, this criticism has a fairly straightforward rebuttal. Subsequent to the housing market crisis of 2008, black homeownership is at an all-time low, and the disparity between the proportion of black and white homeowners is more drastic than it was when race-based housing discrimination was legal (Young 2019). While the ability to build equity is a critical one, as it currently stands, black citizens largely don't have access to homeownership that would result in significant equity building. I argue that it's more important to encourage black homeownership where it's most affordable. Although not producing dramatic gains, not only are black homeowners shielded from volatility in the housing market, but they also have access to financial options that aren't available to renters like a home equity loan or a home equity line of credit, both of which can be used to support education, entrepreneurship, or the pursuit of other properties. In addition, some CLTs allow homeowners to build equity in increasing property value as long as the local average income has similarly increased (Davis 2014). It should also be noted however that CLTs should not be the only program focused on eliminating racial disparities.

On the other hand, a more complicated criticism is often levied upon CLTs: The economic model is inherently incompatible with the community-based ideals. This opinion has been explored at length by law students, community organizers, and policy experts. Essentially, CLTs are perpetually dependent on donors, grants, or other outside funding because the money they earn from the land lease-typically $\$ 30-\$ 45$ a month from residents that live on the land - isn't nearly enough to sustain the entirety of the land trust, especially if new land or development is to be pursued (Foster 2019). Because of this chronic underfunding, the ability of CLTs to function is reliant on the ability to expertly navigate the esoteric and meticulous process of grant applications, which often require comprehensive tax and financial data as a baseline for eligibility.
Although earlier I referenced the accessibility to HUD as a positive milestone in the trajectory of CLTs, as access to federal funding kept many land trusts in business, the ultimate effect has been the 
attrition of the founding principles of community. By the time enough administrative efficiency to engage successfully in the grant allocation process has been established, priorities have often shifted away from community participation and towards the bureaucratic process of pursuing grants and courting donors. In recent years, the leadership of CLTs has drifted away from accountability to community members, and increasingly towards hyper professionalization (Foster 2019). This has also resulted in a regression in the pragmatic outputs of CLTs that mirrors the increasing distance between contemporary profit based CLTs and their ideological predecessors. While this isn't a problem experienced by all CLTs, it is one that is inherent to the structure. Expansion of the program and the benefits it provides isn't possible without economic growth and profit - the very antithesis of CLTs to begin with. This dilemma delivers us to the fourth section of this essay where I argue for the utilization of reparations funding for Community Land Trusts as a means of rectifying the weaknesses of both policies.

\section{The Political Feasibility of CLTs as Government Sponsored Reparations}

The solution to this problem is for local governments to commit to supporting the construction and maintenance of black Community Land Trusts in acknowledgement of their individual histories of racial housing discrimination. As I have argued in this essay, race-neutral policies are ineffective at reducing the racial wealth gap. However, one final conflict remains: in contemporary politics, raceconscious policy has often prompted little interest or traction. Overwhelmingly, unpopularity among voters, particularly white voters, has been referenced and cited as its predominant obstacle (Maris Polling
2016). However, in this final section, I will argue that public opinion about racial policy is dynamic and particularly favorable to progressive policy, particularly at this junction in the U.S.'s political landscape.

A Pew Research study published on October 6, 2020 identified current levels of support for reparations programs. Respondents were polled on their opinions about policies that could rectify racial inequality in America. The results did not support reparations. Even among white Democrats, the percentage of people that believed reparations would be a productive mechanism by which to achieve racial equality topped out at $43 \%$ (Parker 2020). However, there is one caveat to these findings. When polled, all participants were given a definition of reparations that involved the U.S. government paying cash reparations directly to black people who are the descendants of slaves (Parker 2020). I challenge the conclusions of this study on the grounds that it doesn't demonstrate the complexity in race relations, nor is it representative of the model I suggest.

A fundamental inverse relationship between the perceived danger or competition for white people due to the proximity of black communities and support for policy that is at least presumed to support minorities grounds plenty of research on the relationship between public opinion on race and support for progressive policy. This dynamic is explored in Martin Johnson's 2001 article titled, The Impact of Social Diversity and Racial Attitudes on Social Welfare Policy. In it, he describes the dynamic of "group threat" in which white voters' likelihood to support progressive social policy is directly correlational to their feelings about the security of their status as racial majorities. In this model, white Americans are less likely to support social welfare policy if they feel that increasing minority populations will threaten them 
either economically, based on a perceived threat to their employment opportunities and increasing cost of welfare, or socially, based on perceived threat of their cultural values and social dominance (Johnson 2001). However, his paper also introduces the apparent contradiction of a competing theory that dictates that increased exposure to racial diversity increases positive attitudes toward racial minorities, with interpersonal interaction most effective at decreasing racial animus. This was represented by the 1992 New York mayoral election that found white voters that lived in racially diverse neighborhoods - and therefore exposed to more racial diversity in their everyday interactions - voted for incumbent black mayor David Dinkins far more often than white voters living in homogeneous white neighborhoods (Johnson 2001).

Essentially, Johnson argues that both theories can coexist, and there is a threshold below which increasing racial diversity will prompt positive exposure to racial minorities, and therefore improve perception of race relations, while above the threshold, competitive threat sets in and the opposite is true. Neither of these theories are revolutionary, but they do illuminate the fact that public perception, and as an extension of that, support of public policy is more fluid and dynamic than polls might suggest. This general theory of racial resentment has endured for decades, but as reported public support for black Americans and the social problems they face have improved, a reconsideration of this dynamic is demanded.

To return to the question of popularity and consequent political feasibility, I argue first that the preconceived notion of reparations results in misrepresentative data about support for the concept of this type of policy. Because robust polling data of public opinion on modern reparations ideas doesn't yet exist, I will instead briefly reference changing public opinion of race as an issue in the United States and the degree to which Americans believe it should be addressed through policy. To explore this contemporary and specific moment of racial awareness, I'll utilize a Pew Research Center study that was conducted in September of 2020. While opinions on specific policies vary, several trends are noticeable. First, the majority of Americans report having pursued some level of education on the history of racial inequality in the past three months, and overall, increasing proportions of Americans are acknowledging the impacts of historical racial inequality. This includes $49 \%$ of respondents who believe overall that the United States has not made enough progress in terms of achieving racial equality, an increase from $45 \%$ in just 2019 . This trend is consistent across all racial demographics, with, for example, the proportion of Hispanic Americans increasing from 48\% in 2019 to $57 \%$ in 2020 , and the proportion of white Americans who believe racial progress hasn't gone far enough increasing by a smaller but visible margin of $37 \%$ to 39\% (Parker 2020).

Second, in addition to questions regarding personal opinion on race relations, the respondents were also polled on the degree to which they believed reinvigorated antiracist activism over the course of 2020 will result in policy changes. $77 \%$ agreed, with around 1 in 3 respondents believing it would result in major changes, and a slight majority of Americans claiming they had paid more attention to racial issues over the past three months. Third, and most critically, for every question asked, black Americans were the racial group most likely to acknowledge the role that race plays in the inequality in our society and additionally to support mechanisms for rectifying that inequality (Parker 2020). While suppositions 
about increasing representation of black voters in the American electorate won't be addressed in depth in this particular paper, there is growing evidence of the increasing salience of black voters in the U.S. (Albright, Cliff, Gavito 2020). The United States is currently facing a critical juncture in the history and future of race relations, and it must be capitalized on to generate sustainable equality.

\section{Conclusion}

The potential for Community Land Trusts can't be comprehensively explored in this essay. There remain worthwhile inquiries into the effects of CLTs on communities such as the impact that CLTs can have on participation in and engagement with the education system and the labor market. In addition, implementation across various regional locations will require research on varied strategies such as mixed portfolios, cross-subsidies, and scattered-site models (Palmer 2019). However, in this essay I set out to make a case for the inclusion of Community Land Trusts in the already underway movement towards economic reparations, and other race-conscious policies in the United States. This argument is grounded in the belief that race-neutral policies are intrinsically unable to address the worsening racial wealth gap. These policies attempt to address a problem delineated by race with an ineffective proxy and therefore ignore the factor that is most central to the conversation about the racial wealth gap and the policies necessary to overcome it. It is an ideological flaw that begets pragmatic flaws.

In response, I argue my solution proposes a more expansive view of reparations, one that can contend with both the ubiquitous historical legacy of institutionalized racism as well as the dynamic and varied black population that exists today. This requires our discussion of reparations to transcend the limitations of cash payouts. As I have argued, Community Land Trusts fill that role by allowing for access to a housing market that has historically been refused to black citizens. They're sustainable in that this initial access is compounded by future potential for affordability and security, and they're unique in the agency they afford to community members to represent themselves in the proceedings of the land trust. This line of questioning has not only intellectual merits in the form of policy devising and the pursuit of innovative funding alternatives, but it also addresses the enduring relegation of black people to a second-class status in the United States. Although it has gone long unacknowledged, the United States can't embody the ideals of justice and equality upon which it was founded until this inequity has been rectified.

\section{References}

Albright, Cliff and Tory Gavito. 2020. "Opinion: The Way to Keep Georgia Blue." POLITICO, December 14, 2020.

https://www.politico.com/news/magazine/2020/12/14 /georgia-black-voters-democrats-senate-runoffs444590 .

Africatown Community Land Trust. n.d. "ALCT About Us."

http://www.africatownlandtrust.org/about-us/.

New York State Attorney General. 2019. "Attorney General James Grants \$1.6 Million To NYC For Affordable Housing." October 10, 2019. https://ag.ny.gov/press-release/2019/attorneygeneral-james-grants-16-million-nyc-affordablehousing.

Asante-Muhammad, Dedrick et al. 2017. The Road to Zero Wealth: How the Racial Wealth Divide Is Hollowing out America's Middle Class. Prosperity Now.

Barnes, William R. 1980. "A Battle for Washington: Ideology, Racism, and Self-Interest in the Controversy over Public Housing, 19431946." Records of the Columbia Historical Society, 
Washington, D.C. 50: 452-83. http://www.jstor.org/stable/40067831.

Cardwell, Anita. 2018. "State Proposals for Medicaid Work and Community Engagement Requirements." National Academy for State Health Policy. January 29, 2018. https://www.nashp.org/wpcontent/uploads/2018/01/Medicaid-WorkRequirements-Chart_10_31_19_Final.pdf

Choi, Myungshik. 2017. "Can Community Land Trusts Slow Gentrification?" Journal of Urban Affairs 40, no. 3. https://doi.org/10.1080/07352166.2017.1362318.

City of Evanston. n.d. "Evanston Local Reparations." www.cityofevanston.org/government/citycouncil/reparations.

Davis, John Emmeus. 2014. Origins and Evolution of the Community Land Trust in the United States. Lincoln Institute of Land Policy. http://communitywealth.org/sites/clone.communitywealth.org/files/downloads/report-davis14.pdf.

Desai, Sameeksha and Travis Howe. 2020. "Who Doesn't Start a Business in America? A Look at PreEntrepreneurship Leavers." Ewing Marion Kauffman Foundation, November 2020.

https://www.kauffman.org/entrepreneurship/reports/p re-entrepreneurship-leavers-in-america/

DeWolf, Elizabeth. 2018. "The Impact of Community Land Trusts on Neighborhoods." Equality Indicators, February 26, 2018. http://equalityindicators.org/blog/2018/02/26/theimpact-of-community-land-trusts-on-neighborhoods/.

Downey, Liam and Brian Hawkins. 2009. "Race, Income, and Environmental Inequality in the United States." Sociological Perspectives 51, no. 4: 759781. https://doi.org/10.1525/sop.2008.51.4.759.

EdBuild. 2019. "Nonwhite School Districts Get \$23 Billion Less than White Districts Despite Serving the Same Number of Students."

https://edbuild.org/content/23-billion.

Fandos, Nicholas. 2021. "In a Historic Vote, a House Panel Advances a Bill to Form a Reparations Commission.” The New York Times, April 14, 2021. https://www.nytimes.com/2021/04/14/us/housereparations-bill.html.

Foster, Daniel. 2019. "The Limits of Land Reform: A Comment on Community Land Trusts." UCLA Law Review, September 21, 2019. https://www.uclalawreview.org/the-limits-of-landreform-a-comment-on-community-land-trusts/.

Frum, David. 2020. "The Impossibility of Reparations." The Atlantic, July 6, 2020.

https://www.theatlantic.com/business/archive/2014/0 6/the-impossibility-of-reparations/372041/.

Hendley, Alexa and Natasha Bilimoria. 1999. Minorities and Social Security: An Analysis of Racial and Ethnic Differences in the Current Program. Social Security Administration. https://www.ssa.gov/policy/docs/ssb/v62n2/v62n2p5 9.pdf

Huang, Chye-Ching, \& Taylor, Rodrick. 2019. "How the Federal Tax Code Can Better Advance Racial Equity." Center on Budget and Policy Priorities. July 25, 2019. https://www.cbpp.org/research/federaltax/how-the-federal-tax-code-can-better-advanceracial-equity

Johnson, Martin. 2001. "The Impact of Social Diversity and Racial Attitudes on Social Welfare." State Politics \& Policy Quarterly 1, no. 1: 27-49.

Katznelson, Ira. 2005. When Affirmative Action was White. New York: W.W. Norton.

Lipsitz, George. 2018. The Possessive Investment in Whiteness: How White People Profit from Identity Politics. Philadelphia, PA: Temple University Press.

Lipsitz, George. 2008. "Still Separate and Unequal: The State of Fair Housing in America." The National Commission on Fair Housing and Equal Opportunity. https://www.prrac.org/projects/fair_housing_commis sion/chicago/chicago_briefing.pdf

Marist Poll. 2016. Nature of the Sample: Exclusive Point Taken-Marist Poll of 1,221 National Adults. http://maristpoll.marist.edu/wpcontent/misc/usapolls/us160502/Point\%20Taken/Rep arations/Exclusive\%20Point\%20Taken-

Marist\%20Poll_Reparations\%20Banner\%201_May\% 202016.pdf.

McCammon, Sarah. 2015. "The Story Behind ' 40 Acres And A Mule'." National Public Radio, January 12, 2015.

https://www.npr.org/sections/codeswitch/2015/01/12/ 376781165/the-story-behind-40-acres-and-a-mule

McIntosh, Kriston. 2020. "Examining the Blackwhite wealth gap." The Brookings Institution. Feburary 27, 2020.

https://www.brookings.edu/blog/up- 
front/2020/02/27/examining-the-black-white-wealthgap/

NASHP. 2018. "State Proposals for Medicaid Work and Community Engagement Requirements." NASHP. January 2018. https://www.nashp.org/wpcontent/uploads/2018/01/Medicaid-WorkRequirements-Chart_10_31_19_Final.pdf.

Francis, David. "Employers' Replies to Racial Names." National Bureau of Economic Research. September 2003.

http://www.nber.org/digest/sep03/employers-repliesracial-names.

Nelson, Katherine et al. 2020. "The Commodity Effects of Decommodification: Community Land Trusts and Neighborhood Property Values." Housing Policy Debate 30, no. 5. https://doi.org/10.1080/10511482.2020.1768573.

OHCHR. n.d. Basic Principles and Guidelines on the Right to a Remedy and Reparation for Victims of Gross Violations of International Human Rights Law and Serious Violations of International Humanitarian Law.

https://www.ohchr.org/EN/ProfessionalInterest/Pages /RemedyAndReparation.aspx.

Palmer, Analiese. 2019. "Strategies for Sustainable Growth in Community Land Trusts." Joint Center for Housing Studies of Harvard University. March 2019.

Parker, Kim. 2020. “Amid National Reckoning, Americans Divided on Whether Increased Focus on Race Will Lead to Major Policy Change." Pew Research Center's Social \& Demographic Trends Project. November 3, 2020.

https://www.pewsocialtrends.org/2020/10/06/amidnational-reckoning-americans-divided-on-whetherincreased-focus-on-race-will-lead-to-major-policychange/.

Pfingst, Lori et al. 2017. "Creating an Equitable Future in Washington State." African American Leadership Forum-Seattle.

Piketty, Thomas and Arthur Goldhammer. 2017. Capital in the Twenty-First Century. Cambridge Massachusetts: The Belknap Press of Harvard University Press.

Rothstein, Richard. 2018. The Color of Law: a Forgotten History of How Our Government Segregated America. Liveright Publishing Corporation, a Division of W.W. Norton \& Company.
Solow, Robert M. 2014. "Thomas Piketty Is Right." The New Republic, April 23, 2014.

https://newrepublic.com/article/117429/capitaltwenty-first-century-thomas-piketty-reviewed

Taylor, Jamila. 2019. "Racism, Inequality, and Health Care for African Americans." The Century Foundation. December 12, 2019.

https://tcf.org/content/report/racism-inequalityhealth-care-african-americans/

Thaden, Emily. 2011. "Stable Home Ownership in a Turbulent Economy." Lincoln Institute of Land Policy. July 1, 2011. https://www.lincolninst.edu/publications/workingpapers/stable-home-ownership-turbulent-economy.

U.S. Department of Housing and Urban Development. n.d. "Housing Discrimination Under the Fair Housing Act" https://www.hud.gov/program_offices/fair_housing equal_opp/fair_housing_act_overview

Vyas, Darshali et al. (2021). "Hidden in Plain Sight-Reconsidering the Use of Race Correction in Clinical Algorithms." Obstetrical \& Gynecological Survey 76, no. 1: 5-7. https://doi.org/10.1097/01.ogx.0000725672.30764.f7.

Young, Caitlin. "These Five Facts Reveal the Current Crisis in Black Homeownership." Urban Institute. July 31, 2019. https://www.urban.org/urbanwire/these-five-facts-reveal-current-crisis-blackhomeownership. 